\title{
UPACARA TRADISI MASA KEHAMILAN \\ dalam Masyarakat Jawa
}

\author{
Titiek Suliyati
}

Jurusan Sejarah Fakultas Ilmu Budaya Universitas Diponegoro

\begin{abstract}
Javanese society possesses traditional ceremonies to their life cycle and natural phenomenon. These traditional ceremonies conducted from generation to generation carry symbols of good expectations and moral education as local wisdom rooted from the past sociocultural thoughts and senses.This article discusses traditional ceremonies among the Javanese society, focusing on the pregnancy period of Mapati, Tingkepan, Mrocoti, Ndadung and Ndaweti.
\end{abstract}

Key words : traditional ceremonies, pregnancy period, Javanese society

\section{Pendahuluan}

Dalam kehidupan sehari-hari masyarakat Jawa tidak lepas dari upacara-upacara, baik yang terkait dengan daur hidup maupun yang terkait dengan fenomena alam dan peristiwa-peristiwa penting. Masyarakat Jawa sangat mempercayai hal-hal gaib dengan mempraktekannya dalam berbagai upacara tradisi, seperti upacara tradisi tentang asalusul daerah atau suku, upacara tradisi daur hidup, upacara tradisi yang berkaitan dengan kesuburan pertanian dan mata pencaharian (Suseno, 2001: 86-87).

Upacara tradisi daur hidup adalah upacara peralihan tahap (rites of passage) yang digambarkan seperti busur panah, mulai dari peristiwa keseharian yang sederhana, dari tahap kelahiran sampai pada perhelatan-perhelatan besar yang diatur lebih rumit, seperti sunatan atau khitanan, perkawinan dan kemudian berakhir pada upacara kematian yang hening (Geertz, 1989: 48, 104).

Upacara-upacara tradisi ini sarat dengan simbol-simbol yang maknanya berkisar antara harapan-harapan baik dan unsur-unsur pendidikan moral. Masyarakat Jawa dalam semua aspek kehidupannya selalu menerapkan dua falsafah yang berkaitan dengan simbol dasar, yaitu bentuk piramida dan kerucut. Bentuk dasar tersebut dalam pandangan masyarakat Jawa memiliki unsur-unsur yang bersifat vertikal dan horisontal. Unsur-unsur yang bersifat vertikal meliputi hubungan makrokosmos, hubungan dengan alam atas atau 
kekuatan adi-kodrati. Unsur-unsur horizontal meliputi hubungan mikrokosmos yang sifatnya duniawi. Bentuk hubungan horizontal mencakup hubungan sosial, kekerabatan, kemanusiaan dan kehidupan materi.

Pendidikan moral yang dimulai sejak dini diharapkan dapat membentuk karakter yang unggul. Pendidikan moral melalui upacara-upacara tradisi yang telah dilakukan sejak dahulu oleh masyarakat Jawa secara berkesinambungan dari generasi ke generasi. Pendidikan moral tidak hanya terkait dengan kecerdasan akal saja melainkan juga terkait dengan kearifan emosional dan sosial. Pendidikan moral terkait erat dengan pembentukan karakter yaitu pembentukan kepribadian yang menjadi identitas seseorang, karakter yang sifatnya sangat personal terkait dengan cara berpikir, kejiwaan atau emosi dan cara bersosialisasi.

Secara naluriah manusia memiliki sifat-sifat dasar yang cenderung mempetahankan nilai-nilai kebaikan. Nilai-nilai kebaikan yang menjadi landasan pendidikan moral diyakini dapat dimulai sejak anak masih di dalam kandungan. Di lingkungan masyarakat Jawa ada berbagai jenis upacara tradisi yang terkait dengan daur hidup manusia mulai dari anak masih di dalam kandungan ibunya, setelah anak lahir ke dunia, setelah anak menjelang remaja sampai setelah anak dewasa dan setelah meninggal dunia.

Upacara tradisi yang dilakukan di lingkungan masyarakat Jawa terkait erat dengan kearifan lokal, yang berakar dan bersumber dari ajaran-ajaran dan nilai-nilai budaya masyarakat yang telah berlangsung sejak dahulu. Kearifan lokal ini selain mengandung nilainilai dari budaya setempat, juga mengandung nilai-nilai yang sifatnya universal. Karena kandungan nilai-nilai yang sifatnya universal ini kearifan lokal dipandang perlu dijadikan pedoman dalam hidup bermasyarakat.

Tulisan ini membahas tentang upacara-upacara tradisi yang menjadi bagian dari upacara tradisi daur hidup di lingkungan masyarakat Jawa, khususnya upacara tradisi masa kehamilan, yaitu upacara tradisi Mapati untuk menandai usia kehamilan 1 (satu) sampai dengan 5 (lima) bulan, upacara tradisi Tingkepan yaitu untuk menandai usia kehamilan 7 (tujuh ) bulan, upacara tradisi Mrocoti disertai upacara tradisi Ndadung yaitu untuk menandai masa kehamilan 9 (sembilan) bulan. Bila sampai pada saatnya melahirkan dan bayi belum juga lahir pada usia kehamilan memasuki bulan ke 10 (sepuluh) masa kehamilan, atau lebih, maka dilaksanakan upacara Ndaweti . 
Upacara-upacara tradisi pada masa kehamilan merupakan bagian dari upacara tradisi daur hidup yang penting dalam lingkungan masyarakat Jawa karena masa kehamilan merupakan masa awal kehidupan seorang anak dan juga merupakan tahap peralihan status seorang perempuan dari gadis menjadi ibu atau orang tua.

\section{Upacara Tradisi Masa Kehamilan dalam Masyarakat Jawa}

Yang disebut masyarakat Jawa adalah masyarakat yang memiliki budaya Jawa dan secara geografis menempati wilayah Jawa Tengah dan Jawa Timur (Koentjaraningrat, 2002: 329). Upacara tradisi yang hidup di lingkungan masyarakat Jawa merupakan ekspresi budaya yang sudah berlangsung sejak lama. Kebudayaan dan masyarakat pendukungnya merupakan paduan yang sangat erat dalam harmoni kehidupan.

Pandangan Radcliffe-Brown (1965) terhadap upacara tradisi dapat disimpulkan bahwa upacara tradisi memiliki fungsi sosial yang penting dalam kehidupan masyarakat, yaitu untuk menghidupkan ikatan-ikatan solidaritas sosial. Sejalan dengan pandangan Radcliffe-Brown, upacara tradisi di lingkungan masyarakat Jawa merupakan ekspresi alamiah untuk mempererat ikatan-ikatan sosial agar keseimbangan sosial dan keseimbangan kehidupan dunia-akhirat terjaga.

Upacara tradisi memiliki banyak makna simbolik yang penafsirannya tergantung pada pengalaman empirik masyarakat. Pemahaman masyarakat terhadap makna simbolsimbol dalam upacara tradisi diperoleh melalui pengalaman dan pembelajaran yang ditularkan secara turun-temurun dan terus-menerus dari satu generasi ke generasi berikutnya. Upacara tradisi pada masa kehamilan yang sampai saat ini masih sering dilakukan oleh masyarakat Jawa dapat dikategorikan dalam beberapa jenis, yaitu 1) Ngebor-ebori (masa kehamilan 1-4 bulan); 2) Tingkepan (masa kehamilan 7 bulan); 3) Ndadung atau Procotan (masa kehamilan 9 bulan); dan 4) Ndaweti (masa kehamilan 910 bulan).

Kelahiran seorang anak merupakan peristiwa yang sangat dinantikan oleh pasangan suami-istri, sehingga peristiwa kehamilan dianggap sebagai peristiwa penting. Dalam tradisi yang hidup di lingkungan masyarakat Jawa, bila seorang wanita diketahui telah hamil, ada beberapa kegiatan yang dipersiapkan untuk menyambut kehadiran si jabang bayi ke dunia. Upaya untuk menjaga kesehatan dan keselamatan calon ibu dan bayi yang dikandungnya serta anggota keluarga lainnya ditampilkan dalam berbagai upacara tradisi. 
Upacara daur hidup dalam antropologi disebut crisis rites karena upacara-upacara menuju masa peralihan dan perubahan status atau jenjang kehidupan manusia digambarkan penuh hambatan dan tantangan yang dapat membahayakan kehidupan manusia tersebut. Untuk menangkal mara bahaya yang akan menghambat perjalanan hidup manusia, maka kemudian diadakan upacara-upacara (Suwondo, 1981: 157). Dalam kehidupan masyarakat Jawa upacara-upacara ini disebut selametan, yang fungsinya untuk menumbuhkan harapan agar kehidupan manusia selamat dunia-akhirat.

Upacara tradisi untuk wanita hamil dimulai ketika usia kehamilan 1 (satu) bulan, 2 (dua) bulan dan seterusnya. Masa kehamilan usia 1 (satu) sampai dengan 4 (empat) bulan bisanya disebut sebagai masa menyidam atau ngidam, yaitu ketika wanita mengalami hamil muda. Untuk menandai awal kehamilan biasanya diadakan upacara sederhana atau selametan kecil, yang sering disebut banca'an.

Perubahan pola kehidupan masyarakat sangat berpengaruh pada pelaksanaan upacara-upacara tradisi, termasuk upacara tradisi sebelum kelahiran. Saat ini masyarakat Jawa banyak yang tidak melakukan seluruh rangkaian upacara tradisi sebelum kelahiran seperti upacara tradisi menandai kehamilan 1 (satu) sampai dengan 5 (lima) bulan. Beberapa upacara tradisi sebelum kelahiran yang dianggap penting adalah upacara tradisi menandai tujuh bulan kehamilan (tingkepan atau mitoni), kemudian upacara tradisi untuk menandai usia kehamilan 9 (sembilan) bulan yang sering disebut nglolosi atau mrocoti.

Jika sampai pada usia kehamilan 10 (sepuluh) bulan si jabang bayi belum lahir, maka diadakan upacara tradisi sederhana ndadung yaitu leher calon ibu diikat dengan tali oleh suaminya dan dituntun menuju kandang kerbau. Upacara ndadung saat ini jarang dilakukan oleh masyarakat, terutama masyarakat yang tinggal di perkotaan. Sebagian masyarakat yang tinggal di pedesaan masih melakukan upacara tradisi ndadung ini.

Untuk kehamilan bulan ketiga, kelima, dan seterusnya yang urutannya ganjil, diadakan pula upacara tradisi Meteng Medeking yang dilakukan pada saat usia kehamilan menginjak 7 (tujuh) bulan (Proyek Inventarisasi dan Dokumentasi Kebudayaan Daerah Jawa Tengah, 1985-1986: 11).

\section{1. Ngebor-ebori}

Upacara tradisi menandai usia kehamilan 1 (satu) bulan sampai dengan 4 (empat) bulan biasanya diadakan secara sederhana di rumah calon ayah dan ibu, atau di rumah 
orang tua calon ayah atau orang tua calon ibu. Upacara tradisi ini ditandai dengan pembuatan jenang sumsum yaitu bubur dari beras putih yang diberi juruh atau gula aren cair, yang kemudian dibagikan kepada para tetangga dan kerabat.

\section{2. Tingkepan atau Mitoni}

Upacara tingkepan sering disebut mitoni yaitu berasal dari kata Jawa pitu yang artinya 7 (tujuh). Upacara mitoni ini dilaksanakan setelah usia kehamilan mencapai 7 (tujuh) bulan pada kehamilan pertama. Upacara tingkepan ini biasanya dilaksanakan pada tanggal-tanggal yang mengandung nilai 7 (tujuh) yaitu seperti tanggal 7 (tujuh), tanggal 17 (tujuh belas) dan tanggal 27 (dua puluh tujuh). Di antara tanggal-tanggal tersebut,

yang sering dipilih oleh masyarakat Jawa adalah tanggal 27 (dua puluh tujuh), karena tanggal tersebut adalah tanggal yang mengandung nilai 7 (tujuh) yang paling tua dalam bulan tersebut. Waktu untuk melaksanakan upacara biasanya pagi hari sekitar pukul 10.00 atau sore hari sekitar pukul 16.00.

Upacara tingkepan ini dilaksanakan di rumah orang tua calon ibu atau di rumah pribadi pasangan suami istri tersebut. Upacara tingkepan dilaksanakan di ruang depan atau ruang tamu. Untuk acara siraman calon ibu dilakukan di sumur atau kamar mandi. Upacara ini melibatkan beberapa pihak, yaitu pasangan suami istri yang sedang menantikan kelahiran putra atau putrinya, dukun bayi, keluarga dan krabat dekat, serta para tetangga.

Perlengkapan upacara tingkepan yang perlu dipersiapkan meliputi beberapa jenis makanan berupa rujak dari buah-buahan, yaitu 7 (tujuh) macam buah, waluh atau labu, pala penden (umbi-umbian), tumpeng lengkap dengan lauk-pauk ikan laut, ingkung ayam, kuluban atau urap dari sayuran, nasi liwet, ketupat, lepet, 7 (tujuh) macam bubur, jajan pasar (jajanan yang dijual di pasar), dan dawet. Selain bahan-bahan tersebut di atas, ada beberapa perlengkapan lain seperti air dari 7 (tujuh) sumur atau sumber, telur ayam, cengkir (kelapa yang masih muda), kembang setaman atau 7 (tujuh) jenis bunga, 7 (tujuh) lembar kain batik dengan 7 (tujuh) macam motif.

Waktu yang dipilih untuk melaksanakan upacara tingkepan adalah hari yang dianggap baik yaitu hari Selasa (terhitung mulai hari Senin pukul 12.00 sampai hari Selasa sebelum pukul 12.00) dan hari Sabtu (terhitung mulai hari Jum'at pukul 12.00 
sampai hari Sabtu sebelum pukul 12.00). Upacara tingkepan ini biasanya dilaksanakan pada siang atau sore hari.

Tempat upacara biasanya di rumah orang tua calon ibu atau di rumah pasangan suami istri yang mengadakan upacara itu, dengan dipandu oleh orang yang dituakan (sesepuh) atau dukun bayi. Upacara Tingkepan ini dibuka dengan doa yang dipimpin oleh sesepuh atau modin, dilanjutkan dengan acara adat yang berupa siraman yang dilakukan di kamar mandi atau di sumur. Siraman dilakukan oleh 7 (tujuh) wanita yang dihormati sebagai sesepuh, yang secara bergantian menyiram tubuh calon ibu dengan air dari 7 (tujuh) sumber yang telah diberi kembang 7 (tujuh) rupa. Setelah siraman selesai, siwur (gayung yang terbuat dari batok/tempurung kelapa) dan pengaron (tempat air dari tanah liat) dipecah.

Setelah acara siraman dilanjutkan dengan tahapan prosesi berikutnya, yaitu upacara memasukkan telur oleh calon ayah dari bagian atas dada calon ibu ke dalam kain/sarung yang dipakainya sampai telur tersebut meluncur ke bagian bawah. Selanjutnya dilakukan upacara brojolan, yaitu memasukkan dua buah cengkir (kelapa muda) gading yang dilukis wajah pasangan tokoh pewayangan Kamajaya dan Dewi Ratih atau Arjuna dan Sembadra. Ketika dua buah cengkir ini diluncurkan dari atas perut ke dalam kain calon $\mathrm{ibu}$, orang tua perempuan dari pasangan calon ayah dan ibu menerima dua buah cengkir tersebut di bagian bawah tubuh calon ibu. Dua cengkir ini lalu digendong seperti bayi dan diletakkan di atas tempat tidur. Adakalanya di beberapa daerah cengkir gading yang telah dilukis tersebut dibelah oleh calon ayah.

Setelah upacara brojolan dilakukan upacara ganti pakaian. Dalam upacara ini telah disiapkan 7 (tujuh) pasang pakaian yang terdiri dari kebaya warna-warni, kemben dan jarik (kain batik panjang) berbagai motif, seperti Sidomukti, Sidoluhur, Truntum, Parangkusuma, Udan Riris, Cakar Ayam, dan batik Lasem dengan kemben motif Dringin. Di beberapa daerah selain motif jarik seperti tersebut di atas, ada beberapa motif jarik yang agak berbeda seperti motif Wahyu Tumurun, Semen Rama dan Sido Asih. Apapun motif jarik yang digunakan dalam upacara tradisi tingkepan ini selalu dimaknai sebagai sesuatu yang baik, yang diharapkan akan mendatangkan kebahagiaan. Upacara ganti pakaian ini dilakukan di ruang tengah, yang memungkinkan tamu berkumpul. 
Setiap kali calon ibu berganti pakaian, para undangan berseru "durung patut" (belum pantas) sampai pada pakaian terakhir barulah tamu undangan berseru "wis patut " (sudah pantas).

Selanjutnya disusul dengan upacara Medhot Lawe yaitu memutus benang atau kadang janur yang dililitkan di perut calon ibu. Medhot Lawe ini dilakukan oleh calon ayah.

Kadang di beberapa daerah rangkaian upacara ini dilengkapi dengan prosesi Nyolong Endok atau mencuri telur yang dilakukan oleh calon ayah, yang setelah berhasil mencuri telur lalu berlari mengelilingi kampung dengan membawa telur curian. Upacara kemudian ditutup dengan doa dan selametan dengan membagi makanan untuk disantap bersama dan/atau dibawa pulang. Doa yang dibacakan dalam upacara tingkepan ini adalah doa dalam agama Islam. Setelah doa dibacakan oleh Kyai atau Modin, para tamu menikmati hidangan yang telah dipersiapkan dan ketika pulang diberi berkat.

\section{3. Ndadung atau Procotan}

Jika pada usia kehamilan 9 (sembilan ) bulan atau lebih belum ada tanda-tanda akan kelahiran maka diadakan upacara sederhana yaitu upacara Procotan. Pada upacara ini disajikan jenang atau bubur dari tepung ketan dan santan yang dicampur gula merah dan kadang diberi pisang, yang disebut bubur atau jenang Procot, yang dibagikan kepada para tetangga dan kerabat.

Dalam upacara ini leher calon ibu diikat secara longgar dengan dadung atau tali kemudian dituntun oleh calon ayah ke kandang kerbau atau sapi.

\section{4. Ndaweti}

Ketika usia kehamilan memasuki 10 (sepuluh) bulan dan bayi belum lahir, maka dilakukan upacara Ndaweti. Perlengkapan upacara adalah minuman Dawet Plencing yang terbuat dari tepung beras, dengan santan dan gula merah. Dawet ini secara simbolis dijual

kepada anak-anak yang ada di sekitar rumah. Anak-anak membayar dengan kreweng yaitu pecahan genting atau pecahan alat rumah tangga yang terbuat dari tanah liat. Upacara tradisi ini dilaksanakan secara sederhana dan tidak melibatkan Kyai/Modin sebagai pemandu upacara. 


\section{Makna Tatacara dan Perlengkapan Upacara Tradisi Masa Kehamilan}

Upacara untuk menandai usia kehamilan 1-4 bulan dilaksanakan secara sederhana, yaitu hanya dengan pembuatan dan pembagian bubur sumsum dan juruh (sirup gula merah). Makna upacara yang disebut ngebor-ebori adalah memberi tanda bahwa ada calon ibu yang sedang hamil muda atau nyidam (Rumidjah, 1982-1983 : 8). Ubo rampe (perlengkapan upacara) yang berupa bubur sumsum putih merupakan simbol bibit pria berupa sperma yang berproses menjadi janin/bayi dan gula merah sebagai simbol darah; sehingga makna bubur sumsum dan gula merah merupakan tanda menyatunya benih lakilaki dan perempuan dalam wadah (tempat) reproduksi perempuan calon ibu. Upacara ini berfungsi sebagai pemberitahuan bahwa ada calon ibu beserta bayi yang dikandungnya, yang harus dijaga keselamatannya lahir dan batin.

Ubo rampe pada upacara tingkepan lebih lengkap dan tata caranya pun lebih rumit. Hal ini dapat dimaklumi karena masa kehamilan 7 (tujuh) bulan merupakan masa persiapan lahir dan batin untuk menerima kelahiran jabang bayi. Harapan-harapan, permohonan keselamatan dan ungkapan sukacita ditampilkan dalam perlengkapan dan tatacara upacara tingkepan.

Beberapa jenis makanan yang menjadi pelengkap tingkepan memiliki makna khusus yang berkaitan dengan harapan dan doa agar calon ibu dan bayi yang dikandungnya selamat dan tidak mendapat rintangan ketika menjalani proses kelahiran. Sajian berupa rujak dari 7 (tujuh) macam buah-buahan menjadi tanda bahwa calon ibu yang ngidam sangat menggemari rujak, yang merupakan sajian yang sederhana tetapi

mengandung berbagai macam rasa seperti asam, manis, asin, dan bermakna kehidupan dunia dengan berbagai rasa dan tantangan, yang harus dihadapi dengan rasa optimis dan senang. Sajian makanan lain dapat diartikan sebagai berikut.

Waluh (labu) disamakan artinya dengan waluyo yaitu artinya mulia; pala pendem (umbi-umbian) melambangkan kesuburan dan kemakmuran. Tumpeng yang tersusun dari nasi liwet yang lengkap dengan lauk-pauk ikan laut, ingkung ayam, kuluban (urap dari sayuran) melambangkan dunia beserta isinya; bentuk tumpeng yang mengerucut menyerupai gunung bermakna pemujaan kepada Tuhan Yang Maha Esa, yang secara keseluruhan mengandung falsafah hubungan vertikal dan horisontal, yaitu hubungan antara manusia dengan Sang Maha Pencipta dan hubungan antara sesama manusia, atau 
dalam Islam dikenal dengan hablumminallaah dan hablumminannaas. Ketupat dan lepet bermakna besarnya harapan agar bayi yang akan dilahirkan selalu menyadari kesalahan dan kekurangannya serta selalu berhati-hati sehingga tidak membuat kesalahan. Kemudian, 7 (tujuh) macam bubur bermakna harapan akan perolehan kemudahan dan kelancaran hidup; sedangkan jajan pasar (jajanan atau makanan ringan yang dijual di pasar) yang sederhana dan enak rasanya bermakna agar bayi yang dilahirkan kelak bersifat sederhana, menyenangkan dan dapat bergaul dengan berbagai macam golongan; dan dawet yang dikenal sebagai minuman yang menyegarkan bermakna harapan agar bayi yang akan dilahirkan dianugerahi hidup yang manis dan rejeki yang berlimpah sebagaimana butiran-butiran dawet.

Lebih dari itu, makna siraman atau mandi dengan air dari 7 (tujuh) sumber dan bunga 7 (tujuh) rupa merupakan upaya pembersihan diri lahir dan batin, serta upaya pensucian diri dari dosa dan permohonan ampunan kepada Yang Maha Kuasa. Jumlah perlengkapan upacara yang serba 7 (tujuh) menjadi penegasan bahwa masa kehamilan tujuh bulan adalah masa yang penting. Siraman yang dilakukan oleh 7 (tujuh) orang sesepuh bermakna pemberian doa restu dari para sesepuh agar calon ibu dan bayi yang dikandungnya selamat dan sehat. Setelah acara siraman selesai, siwur dan pengaron (kuali tempat air mandi) dipecah, ini bermakna untuk tolak-bala atau menyingkirkan hambatan dengan harapan jabang bayi dan ibunya selamat.

Upacara siraman dilanjutkan dengan memasukkan telur ke dalam jarik (kain batik) yang dipakai calon ibu melalui bagian atas perut sampai telut tersebut pecah. Telur yang diluncurkan dari atas perut calon ibu dimaknai sebagai harapan agar proses kelahiran bayi lancar tanpa hampatan seperti telur yang meluncur dari atas ke bawah. Setelah itu dilaksanakan upacara brojolan, yaitu memasukkan 2 (dua) buah cengkir (kelapa muda) gading (warna kuning) yang telah dilukis wajah Kamajaya dan Dewi Ratih atau Arjuna dan Sembadra yang bermakna harapan bahwa jika bayi yang akan dilahirkan laki-laki akan memiliki wajah setampan Kamajaya atau Arjuna dan jika yang dilahirkan bayi perempuan akan memiliki wajah secantik Dewi Kamaratih atau Sembadra. Dalam beberapa upacara tradisi cengkir dimaknai dari sebutan namanya yaitu kencengè pikir yang artinya adalah "kuatnya pikiran atau teguhnya tekad." 
Makna dari upacara ganti pakaian sebanyak 7 (tujuh) kali adalah bahwa calon ibu diharapkan dapat membawa diri di tengah kehidupan bermasyarakat, berperilaku pantas, sopan dan menyenangkan. Pemakaian 7 (tujuh) lembar jarik dengan berbagai motif secara bergantian oleh calon ibu mengandung makna harapan-harapan baik terhadap bayi yang akan dilahirkan. Motif sidomukti bermakna harapan agar jabang bayi kelak mencapai kemuliaan, motif Sidoluhur bermakna agar kelak bayi yang lahir memiliki jiwa luhur, motif Truntum bermakna kemuliaan dan cinta kasih yang tidak pernah pudar, motif Parang Kusuma (bunga yang sedang mekar) bermakna kebahagiaan, motif Udan Riris (hujan gerimis) bermakna harapan agar anak yang akan dilahirkan membawa suasana yang menyegarkan dan menyejukkan hati, motif Cakar Ayam bermakna harapan agar anak mandiri dalam menempuh kehidupan, motif Wahyu Tumurun bermakna harapan agar anak yang dilahirkan selalu memegang tali hubungan dengan Tuhan Yang Maha Esa dan taat dalam menjalankan perintah agamanya, motif Semen Rama melambangkan cinta kasih dari ayah dan ibu (orang tua) yang tidak terputus kepada anak dan keluarganya, motif Sido Asih melambangkan harapan agar bayi yang dilahirkan kelak memiliki jiwa yang penuh kasih serta dikasihi oleh masyarakat di lingkungannya. Selanjutnya, kain Batik Lasem dengan motif garis vertikal yang sederhana, yang dipakai pada urutan terakhir dalam upacara ganti busana, melambangkan kesederhanaan hidup dan ketakwaan yang selayaknya selalu dijalankan oleh bayi yang akan dilahirkan; sedangkan Kemben (kain penutup dada) Dringin, yaitu kain tenun sutera dan benang emas dengan motif garis horizontal, bermakna harapan agar bayi yang akan dilahirkan dapat bergaul dan diterima oleh lingkungannya dengan baik.

Upacara Medhot Lawe yaitu calon ayah memutus benang atau janur (daun kelapa) yang dililitkan di perut calon ibu bermakna menyingkirkan segala rintangan dan hambatan dalam proses kelahiran, sehingga bayi lahir dengan selamat. Di beberapa daerah ada upacara Nyolong Endok yaitu mencuri telur yang dilakukan oleh calon ayah, yang bermakna harapan agar proses persalinan berjalan cepat, secepat pencuri telur ketika melarikan diri.

Upacara Procotan yang dilakukan pada usia kehamilan 9 (sembilan) bulan atau lebih dengan sajian bubur atau jenang Procot bermakna harapan agar bayi yang dikandung segera lahir dengan lancar tanpa halangan. Makna dari ndadung leher calon 
ibu dan kemudian menuntunnya ke kandang kerbau atau sapi adalah agar kelahiran bayi tidak menyulitkan, yang diibaratkan seperti kelahiran sapi atau kerbau. Sedangkan makna upacara Ndaweti adalah harapan agar bayi yang dikandung segera lahir dengan lancar, ibarat proses pembuatan Dawet yang meluncur cepat dari alat cetakannya. Nama minuman ini disebut Dawet Plencing karena setelah anak-anak minum dawet mereka pulang dengan berlari kencang.

Secara umum upacara tradisi Ngebor-ebori (masa kehamilan 1-4 bulan), Tingkepan (masa kehamilan 7 bulan), Ndadung atau Procotan (masa kehamilan 9 bulan), Ndaweti (masa kehamilan 9-10 bulan) bermakna harapan agar jabang bayi yang sedang dikandung beserta calon ibu dalam keadaan sehat lahir dan batin, dan diharapkan bayi lahir dengan selamat, sehat dan tanpa ada halangan. Selanjutnya setelah dilahirkan bayi diharapkan mendapat kebahagiaan sepanjang hidupnya.

\section{Kesimpulan}

Upacara tradisi untuk masa kehamilan yang berkaitan dengan daur hidup masyarakat Jawa telah dilakukan sejak dahulu, yaitu pada masa sebelum kedatangan Islam di Indonesia, masa budaya Hindu. Ciri-ciri budaya Hindu sangat kental dengan upacara-upacara tradisi di Jawa, seperti pemujaan kepada leluhur dan hadirnya kekuatankekuatan alam yang sangat mempengaruhi kehidupan di dunia. Selain itu unsur-unsur budaya Hindu juga tampil pada pemaknaan perlengkapan upacara tradisi seperti sesaji dan lain sebagainya.

Pada perkembangannya upacara tradisi yang dilakukan masyarakat Jawa mengalami perkembangan dan perubahan. Ketika budaya Islam merembes masuk ke dalam budaya dan tradisi lokal yang dilandasi Hindu, lambat laun upacara tradisi juga memasukkan unsur-unsur Islam terutama pada doa-doa yang menyertai upacara tradisi tersebut. Perkembangan teknologi dan globalisasi telah merubah fungsi dan esensi dari upacara tradisi masyarakat dalam Jawa. Kegiatan masyarakat yang padat dalam upaya memenuhi kebutuhan hidup menyebabkan masyarakat memiliki waktu yang terbatas untuk melaksanakan upacara tradisi, sehingga saat ini masyarakat hanya melaksanakan upacara tradisi yang dianggap penting. Perlengkapan dan tata cara yang rumit dalam upacara tradisi juga mulai disederhanakan, sehingga pemaknaan upacara tradisi hanya sebagai sarana untuk menjalin hubungan sosial kemasyarakatan dan kekeluargaan. 


\section{Daftar Pustaka}

Geertz, Clifford. 1989. Abangan, Santri, Priyayi dalam Masyarakat Jawa (terjemahan oleh Aswab Mahasin). Jakarta: Pustaka Jaya.

Koentjaraningrat. 1993. Ritus Peralihan di Indonesia. Jakarta: Balai Pustaka. . 2002. Manusia dan Kebudayaan di Indonesia. Jakarta: Djambatan.

Proyek Inventarisasi dan Dokumentasi Kebudayaan Daerah Jawa Tengah. 19851986.

Radcliffe-Brown, A. R. 1965. Structure and Function in Primitive Society. New York: The Free Press.

Rumidjah, Jumeri Siti (Penerjemah). 1982-1983. Serat Tatacara. Yogyakarta: Balai Kajian Sejarah dan Nilai Tradisional, Direktorat Jenderal Kebudayaan, Departemen Pendidikan dan Kebudayaan.

Suseno, Franz-Magnis. 2001. Etika Jawa. Jakarta: Gramedia.

Suwondo, Bambang, et. al. 1981. Adat Istiadat Daerah-daerah Istimewa Yogyakarta. Jakarta: Departemen Pendidikan dan Kebudayaan. 